\title{
SAFETY AND IMMUNOGENICITY OF HEPATITIS B VACCINE BUTANG IN ADULTS
}

\author{
Luzia M. IOSHIMOTO(1), Maria Lúcia RISSATO(2), Valentina S.J. BONILHA(2), Cosue MIYAKI(1), Isaias RAW(3) \& Nikolai GRANOVSKI(4)
}

\section{SUMMARY}

Recombinant yeast-derived hepatitis B vaccine manufactured by Instituto Butantan was administered in two groups of adult volunteers (I, II) following two different schedules of immunization. In the first trial $(10 \mu \mathrm{g}$ doses and $0,1,3$ months vaccination schedule) 106 individuals completed the full immunization program. The results of seroconversion by age group varied from 70 to $100 \%$ and the GMT from 46.5 to $124.9 \mathrm{mIU} \mathrm{mL}^{-1}$. In the second trial with 68 individuals (for dosage comparison and $0,1,6 \mathrm{months}$ vaccination schedule) indicated that the vaccine formulated in $20 \mu \mathrm{g}$ was more effective than in $10 \mu \mathrm{g}$. The adverse reactions observed in the vaccinees were less frequent than the ones previously found since the introduction of similar vaccines.

KEYWORDS: Hepatitis B vaccine; Clinical trials.

\section{INTRODUCTION}

Hepatitis B is an extremely serious disease parenterally/sexually transmitted, representing the 9 th cause of morbidity and mortality in the planet. The infection with hepatitis B virus (HBV) leads to a variety of clinical manifestations: fulminant, acute, chronic and inapparent. Fulminant and acute forms are severe and cause of high mortality. Chronic hepatitis is the form responsible for virus spreading and can potentially progress to cirrhosis and liver cancer. When the infection occurs in early age (newborns to 1 year) the evolution to a chronic state is about $90 \%$, decreasing with the age ${ }^{4}$. More than one million chronic carriers die every year ${ }^{13}$. The HBV is spread in Brazil in regions of low, medium and high prevalence: in the South the incidence is about 0.3 to $1.7 \%$, in São Paulo and Rio de Janeiro from 1.0 to $2.1 \%$ and in the Amazon region from 2.8 to $10.3 \%$ of the population ${ }^{3}$.

Prevention by vaccination is the only effective strategy to avoid the disease. Since 1987 two licensed yeast derived recombinant vaccines containing the major hepatitis virus surface protein (S-protein, $\mathrm{HBsAg}$ ) were available, manufactured by Merck Sharp Dohme (USA) and Smith Kline Beecham (Belgium) and they are still leading the market of HB vaccine $^{6}$. Evaluation made by FDA (Food and Drug Administration) recognized the safety of hepatitis B vaccine based on 12 millions doses administered to babies up to 12 months age ${ }^{8}$. Tiredness, erythema and soreness in the local of injection are the most common side effects observed mostly concerned to the aluminum hydroxide present in formulated product as vaccine adjuvant. The Advisory Committee on Immunization Practice of the Centers for Disease Control and Prevention (CDC) and the American Academy of Pediatrics recommended the vaccination as the only practical means to reduce the $\mathrm{HBV}$ incidence in the USA ${ }^{9}$. In China there was a drastic reduction of $60 \%$ of new cases due to the application of an immunization program for newborns ${ }^{10}$.

The Instituto Butantan in São Paulo (Brazil) produces a recombinant yeast-derived Hepatitis B vaccine (ButaNG) by technology developed in cooperation with N.G. Biotecnologia Ltda. The vaccine is manufactured and quality controlled following the requirements established by World Health Organization and belongs to the new generation of safe vaccines. The vaccine contains highly purified recombinant HBsAg particles produced in yeast Hansenula polymorpha and formulated in aluminum hydroxide. Initially ButaNG was formulated in adult dose containing $10 \mu \mathrm{g}$ of $\mathrm{HBsAg}$, based on results of mice immunization experiments utilizing simultaneously Engerix B vaccine as a reference. Engerix was selected due to its well known efficacy. The vaccination followed the schedules approved by FDA of 0, 1, 6 and 0, 1, 3 and 12 months.

The Instituto Butantan is ready to supply the national vaccine demand for a mass immunization program estimated to be around 30 millions annual doses.

\section{MATERIALS AND METHODS}

Vaccines: ButaNG lots: $9709141(10 \mu \mathrm{g}$ protein, $0.25 \mathrm{mg}$ $\mathrm{Al}^{+++} /$dose); 9710151 (10 $\mu \mathrm{g}$ protein, $0.25 \mathrm{mg} \mathrm{Al}{ }^{+++} /$dose); 9710154 (20 $\mu \mathrm{g}$ protein, $0.25 \mathrm{mg} \mathrm{Al}^{+++} /$dose)

Engerix B lots: 2202A4, 2243A4 and 2272B4 (20 $\mu \mathrm{g}$ protein, $0.50 \mathrm{mg} \mathrm{Al}{ }^{+++} /$dose)

\footnotetext{
(1) Centro de Biotecnologia-Instituto Butantan. Av. Vital Brasil 1500, 05503-900 São Paulo-SP, Brazil.

(2) Fundação Amaral Carvalho. R. Dona Silvéria 150, 17210-080 Jaú-SP, Brazil.

(3) Fundação Butantan. Av. Vital Brasil 1500, 05503-900 São Paulo-SP, Brazil.

(4) N.G.Biotecnologia Ltd. R. Professor Arnaldo Laurindo 160, São Paulo-SP, Brazil.

Correspondence to: Luzia M. Ioshimoto, Centro de Biotecnologia-Instituto Butantan. Av. Vital Brasil 1500, 05503-900 São Paulo-SP, Brazil
} 
ButaNG vaccine was initially formulated in aluminum hydroxide in doses of $10 \mu \mathrm{g} / \mathrm{mL}$ based on the comparative results obtained when ButaNG and Engerix B (used as reference vaccine) were injected in $\mathrm{BALB} / \mathrm{c}$ mice. Doses of $0.5 \mu \mathrm{g}$ of protein per animal were inoculated in groups of 20 mice, in a single shot. Blood samples collected 30 days after inoculations were analyzed by ELISA kits (AUSAB-EIA, Abbott Lab.). The results are presented in Table 1.

\section{Subjects}

The volunteers (18-57 years) were recruited from the Hospital's staff of Fundação Amaral Carvalho, Jaú-SP. The criteria for selection was restricted to the absence of any serological HBV markers assayed by Abbott Lab. kits (Corzyme, Auszyme, Ausab) or to serious health problems.

The reactogenicity was observed after each dose when the patients were inquired for abnormalities such as: injection site pain, headache, fever, fatigue, influenza like symptoms, diarrhea and others.

\section{Study design}

The first trial with group I started with 180 individuals aged 18-57 years. They were injected intramuscularly in the deltoid region with $10 \mu \mathrm{g}$ of ButaNG lot 9709141, amount of protein estimated by the results obtained with mice experiments (Table 1). The schedule of immunization was $0,1,3$ months.

Based on the results of immunogenicity obtained for group I of vaccinees, a second trial in group II of 68 individuals aged $18-50$ years

Table 1

Comparative potency of different lots of ButaNG and reference vaccine, in $\mathrm{BALB} / \mathrm{c}$ mice

\begin{tabular}{lcc}
\hline Vaccine lot\# & $\begin{array}{c}\text { Seroconversion } \\
(\%)\end{array}$ & $\begin{array}{c}\text { Anti-HBs GMT } \\
\left(\mathrm{mIU} \mathrm{mL}^{-1}\right)\end{array}$ \\
\hline EngerixB & 80 & 63.7 \\
2202A4 & 25 & 142.2 \\
& 100 & 151.2 \\
EngerixB & 93 & 239.6 \\
2243A4 & 70 & 138.7 \\
& 80 & 151.8 \\
EngerixB & 93 & 84.0 \\
2272B4 & 100 & 124.9 \\
& 10 & 26.5 \\
ButaNG & 75 & 158.3 \\
9709141 & 75 & 125.4 \\
ButaNG & 100 & 310.8 \\
9709151 & 92 & 152.9 \\
& 100 & 142.4 \\
ButaNG & 100 & 264.0 \\
9710154 & 100 & 130.0 \\
& 100 & 117.7 \\
\hline
\end{tabular}

was initiated. This group was homogeneously subdivided in: A, B, C, D subgroups, considering the age, sex and factor weight/height and vaccinated with ButaNG 9709141, 9710151, 9710154 and Engerix B $2243 \mathrm{~A} 4$, respectively. They were injected in the deltoid muscle following the normal recommended schedule of $0,1,6$ months.

Blood specimens were collected from volunteers before the first injection and evaluated to be negative for the presence of hepatitis $\mathrm{B}$ surface antigen (HBsAg) and antibodies to core antigen (anti-HBc) and to HBsAg (anti-HBs). Samples collected from vaccinees one month after receiving the third shot were tested for anti-HBs. Antibodies were measured in GMT (geometric mean titer) expressed in $\mathrm{mIU} \mathrm{mL}^{-1}$ All blood specimens were tested following the instructions of enzymelinked immunosorbent assay kit (AUSAB-EIA, Abbott Lab.).

Seroconversion was defined as antibody GMT $\geq 2.1 \mathrm{mIU} \mathrm{mL}^{-1}$ and seroprotection as $\geq 10 \mathrm{mIU} \mathrm{mL}^{-1}$.

\section{RESULTS AND DISCUSSION}

\section{Safety}

Short term adverse reaction data reported by individuals from group I after receiving the first shot were injection site soreness $(21.7 \%)$ sometimes accompanied by erythema, fatigue or headache $(4.3 \%)$ and low fever (1.6\%). Reactions were less frequent with subsequent doses. The symptoms, mainly the arm soreness were less frequent than the ones reported regarding recombinant hepatitis B vaccines ${ }^{1,12}$. Adverse reactions reported by group II were basically arm soreness in $30 \%$ of vaccinees after receiving the first dose of Engerix B and in $20 \%$ of individuals who received ButaNG. The less frequent reactions observed can be attributed to the low concentration of aluminum present in the formulation of ButaNG.

The immune response to ButaNG 9709141 in the 106 individuals of group I is shown in Table 2 divided by age groups. The seroconversion decreased with age and the GMT was significantly lower after the age 35. A lower anti-HBs GMT than those found for similar vaccines was expected due to the short schedule of immunization utilized ${ }^{2,5,7}$. Previous published data showed that intervals of 5 to 10 months between the second and third doses maximized the antibody response ${ }^{11}$. In this

\section{Table 2}

Immune response to ButaNG vaccine in pediatric dose $(10 \mu \mathrm{g})$ in group I of 106 vaccinees separated by age group

\begin{tabular}{|c|c|c|c|c|}
\hline \multirow{2}{*}{$\begin{array}{l}\text { Age } \\
\text { (years) }\end{array}$} & \multirow{2}{*}{ number } & \multirow{2}{*}{$\begin{array}{c}\text { serocon } \\
\text { version } \\
(\%)\end{array}$} & \multicolumn{2}{|c|}{ anti-HBs GMT* } \\
\hline & & & $\left(\mathrm{mIU} \mathrm{mL}^{-1}\right)$ & $\begin{array}{c}\geq 10 \mathrm{mIU} \mathrm{mL}^{-1} \\
(\%)\end{array}$ \\
\hline $18-25$ & 21 & 100 & 124.9 & 86 \\
\hline $25-34$ & 42 & 88 & 140.9 & 80.5 \\
\hline $35-44$ & 33 & 85 & 55.9 & 78.5 \\
\hline $45-57$ & 10 & 70 & 46.5 & 100 \\
\hline
\end{tabular}

*Serum anti-HBs levels measured with ELISA kits (Ausab EIA-Abbott Lab.). in GMT (geometric mean titer).

$10 \mathrm{mIU} \mathrm{mL}^{-1}$, protective antibody level. 


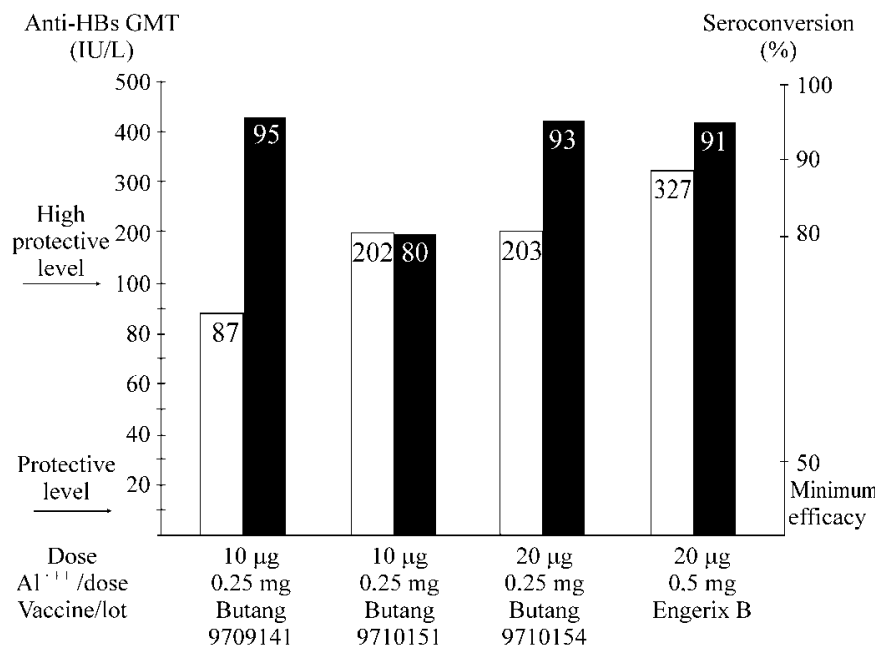

Fig. 1 - Comparative potency in group II of different lots and doses in terms of anti-HBs GMT ( $\square$ ) and seroconversion ( $\square$ ).

group the highest titer was $1597 \mathrm{mIU} \mathrm{mL}^{-1}$. For the seronegative individuals or to those who showed GMT under $10 \mathrm{mIU} \mathrm{mL}^{-1}$ (protective level) a booster in the 12 month was recommended.

As the immune response to $10 \mu \mathrm{g}$ of $\mathrm{HBsAg}$ did not confirm the enhanced immunogenicity observed in mice experiments (Table 1), it directed us to use a second study design in order to determine some suspected reasons: lower concentration of antigen and aluminum than those used in the formulation of similar vaccines and shorter schedule of immunization usually applied to individuals under risk of infection.

The 68 subjects aged 18-50 were distributed in subgroups A, B, C, $\mathrm{D}$ and vaccinated with different vaccine lots, doses and with reference vaccine by the schedule of 0,1 and 6 months. Figure 1 shows the comparative potency of vaccines ButaNG formulated in doses of 10 and $20 \mu \mathrm{g}$ with Engerix B in dose of $20 \mu \mathrm{g}$. The difference between the GMTs determined for 10 and $20 \mu \mathrm{g}$ doses shows that the antigen concentration in the vaccine has to be increased and tested in bigger population. The highest titer detected in $\mathrm{mIU} \mathrm{mL}^{-1} /$ the standard deviation (std.dv.) for subgroups A, B, C and D were 540/141, 646/244, 560/190 and 597/191, respectively.

The clinical trials with ButaNG vaccine was considered satisfactory in terms of low rate of reactogenicity, absence of any incapacitating side effects, seroconversion equivalent to similar vaccines and induction of protective levels of antibodies. The response to $20 \mu \mathrm{g}$ ButaNG (GMT $\left.203 \mathrm{mIU} \mathrm{mL}^{-1}\right)$ is superior than the titer considered as high protective level (100 $\left.\mathrm{mIU} \mathrm{mL}^{-1}\right)$.

The vaccine has the potency to have its efficacy improved by optimizing the formulation by the introduction of different adjuvants or simply by adjusting the concentration of all vaccine components.

\section{RESUMO}

Inocuidade e imunogenicidade da vacina contra a hepatite $B$, ButaNG, em adultos
Vacina contra a hepatite B, produzida no Instituto Butantan em levedura recombinante, foi administrada em dois grupos de voluntários adultos (I e II) seguindo dois esquemas diferentes de imunização. No primeiro ensaio (doses de $10 \mu \mathrm{g}$ e esquema de vacinação de $0,1,3$ meses), 106 indivíduos completaram o programa de imunização proposto. Os resultados de soroconversão agrupados por faixa etária variaram de 70 a $100 \%$, enquanto que o TGM foi de 46,5 a $124 \mathrm{mUI} \mathrm{mL}^{-1}$. No segundo ensaio com 68 indivíduos (comparação de doses e esquema de vacinação de $0,1,6$ meses) os resultados indicaram que a vacina formulada em dose de $20 \mu \mathrm{g}$ foi mais eficaz que em dose de $10 \mu \mathrm{g}$. Os efeitos adversos observados nos vacinados foram menores do que os relatados por outros autores, desde o início da aplicação de vacinas similares.

\section{REFERENCES}

1. ANDRÉ, F.J. \& SAFARY, A. - Summary of clinical finding on Engerix-B, a genetically engineered yeast-derived hepatitis B vaccine. Postgrad. med. J., 63 (suppl. 2): 169-178, 1987.

2. BERGAMINI, F. \& ZANETTI, A. - Immunogenicity of yeast-derived hepatitis B vaccines in young adults. Postgrad. med. J., 63 (suppl. 2): 137-138, 1987.

3. CARRILHO, F.J. \& SILVA, L.C. - Epidemiologia 5. In: SILVA, L.C., ed. Hepatites. São Paulo, Sarvier, 1986. p. 47-69.

4. COURSAGET, P.; YVONNET, B. \& CHOTARD, J. - Age and sex related study of hepatitis B virus chronic carrier area in infants from an endemic area. J. med. Virol., 22: $1-5,1987$.

5. GOUDEAU, A.; DENIS, F.; MOUNIER, M. et al. - Comparative multicentre study of the immunogenicity of different hepatitis B vaccines in healthy volunteers. Postgrad. med. J., 63 (suppl. 2): 125-128, 1987.

6. GRANOVSKI, N. - Recombinant hepatitis B vaccine: the usage of yeast Saccharomyce cerevisiae expression system. Rev. Farm. Bioq. Univ. S. Paulo, 32: 61-70, 1997.

7. KUWERT, E.; SCHEIERMANN, N.; GESEMANN, M. et al. - Dose range study in healthy volunteers of a hepatitis B vaccine produced in yeast. Antiviral Res., (suppl. 1): 281-288, 1985

8. HEPATITIS WEEKLY. Birmingham, C.W. Henderson, October 21, 1997. p. 3.

9. HEPATITIS WEEKLY. Birmingham, C.W. Henderson, October 21, 1997. p. 2.

10. HEPATITIS WEEKLY. Birmingham, C.W. Henderson, December 8, 1997. p. 9-10.

11. JILG, W.; SCHMIDT, M. \& DEINHARDT, F. - Vaccination against hepatitis B: comparison of three different vaccination schedules. J. infect. Dis., 160: 766-769, 1989.

12. JUST, M.; BERGER, R. \& JUST, V. - Reactogenicity and immunogenicity of a recombinant hepatitis B vaccine compared with plasma-derived vaccine in young adults. Postgrad. med. J., 63 (suppl. 2): 121-123, 1987.

13. WORLD HEALTH ORGANIZATION - Global plan of action for hepatitis B immunization. Meeting on the Scientific Advisory Group of Experts, 17-19 October, 1994 H.Q. Geneva, WHO, 1994

Received: 22 October 1998

Accepted: 19 April 1999 